\title{
A Ralstonia solanacearum Strain from Guatemala Infects Diverse Flower Crops, Including New Asymptomatic Hosts Vinca and Sutera, and Causes Symptoms in Geranium, Mandevilla Vine, and New Host African Daisy (Osteospermum ecklonis)
}

\begin{abstract}
Jordan Weibel and Tuan Minh Tran, Department of Plant Pathology, University of Wisconsin-Madison 53706; Ana Maria Bocsanczy, Department of Plant Pathology, University of Florida MFREC, Apopka 32703; Margery Daughtrey, Cornell University Long Island Horticultural Research and Extension Center, Riverhead, NY 11901; David J. Norman, Department of Plant Pathology, University of Florida MFREC, Apopka 32703; Luis Mejia, Facultad de Agronomía, Universidad de San Carlos de Guatemala, Guatemala City Guatemala; and Caitilyn Allen, Department of Plant Pathology, University of Wisconsin-Madison 53706
\end{abstract}

Accepted for publication 28 April 2016. Published 26 May 2016.

\section{ABSTRACT}

Weibel, J., Tran, T. M., Bocsanczy, A. M., Daughtrey, M., Norman, D. J., Mejia, L., and Allen, C. 2016. A Ralstonia solanacearum strain from Guatemala infects diverse flower crops, including new asymptomatic hosts Vinca and Sutera, and causes symptoms in geranium, mandevilla vine, and new host African daisy (Osteospermum ecklonis). Plant Health Prog. 17:114-121.

A strain of Ralstonia solanacearum was associated with wilting and blight of flowering ornamentals grown from cuttings that originated in Guatemala. This isolate, UW757, could wilt geranium, Osteospermum spp., and mandevilla, but was more aggressively virulent on tomato. Although it rarely caused symptoms, after inoculation UW757 colonized the stems of 11 widely grown ornamental species, reaching mean populations as high as $10^{9} \mathrm{CFU} / \mathrm{g}$ stem at the common tropical highland production temperature of $24^{\circ} \mathrm{C}$. UW757 belongs to phylotype I, sequevar 14 of the $R$. solanacearum species complex, not to the Race 3 biovar 2 Select Agent group that also infects geraniums. Whole genome sequencing revealed that UW757 is closely related to several Asian $R$ solanacearum strains and also to P781, a mandevilla-infecting strain established in Florida. Strains similar to UW757 were isolated from tomato in Guatemala in 2006 and 2015, indicating that this group is common and persistent. This finding enlarges the known host range of $R$. solanacearum, which was not previously known to infect Osteospermum, Vinca, or Sutera spp. Growers should be aware that a broad range of ornamental plants, including previously unknown hosts, can be latently infected by non-Race 3 biovar 2 strains of $R$. solanacearum that are also highly virulent on tomato.

\section{INTRODUCTION}

The vascular wilt pathogen Ralstonia solanacearum has an unusually broad host range that spans over 50 plant families and includes many ornamental crops, including anthurium, hydrangea, mandevilla, and geranium (Hayward 1991, 1994a; Swanson et al. 2005; Ji et al. 2007; Wicker et al. 2007). Ralstonia solanacearum, which is transmitted by soil, water, and cutting knives, colonizes host xylem vessels where it can reach cell densities greater than $10^{9}$ colony forming units (CFU)/g stem (Denny 2006). Infected plants may be stunted, yellowed, or unilaterally wilted, and eventually die. Alternatively, $R$. solanacearum can form latent or asymptomatic infections, defined here as plants that contain large bacterial populations but show no symptoms. These plants, which may or may not eventually develop disease, are difficult to detect and can spread the pathogen (Hayward 1991; Swanson et al. 2007).

Ralstonia solanacearum is a heterogeneous species complex that contains thousands of genetically distinct strains (see sidebar, Classification of Plant Pathogenic Ralstonia Species). Phylogenetic analyses have subdivided it into four phylotypes that

Corresponding author: Caitilyn Allen. Email: callen@wisc.edu. correspond to geographic origin, although human activity has now distributed $R$. solanacearum strains across six continents (Fegan and Prior 2005). For example, a subgroup of phylotype II that causes potato brown rot disease originated in the South

\section{Classification of Plant Pathogenic Ralstonia Species}

Plant pathogenic bacteria in the genus Ralstonia form the Ralstonia solanacearum species complex (RSSC), a group of heterogeneous but related strains (Fegan and Prior 2005). This group was historically divided into biovars, based on acidification of carbohydrates, and races, based very loosely on host range (Hayward 1964, 1994b). Unfortunately, neither system is biologically predictive or phylogenetically meaningful. The term "race" is especially problematic because there is no phenotypic or genetic test that can determine the race of a given isolate. There is one coherent group, Race $\mathbf{3}$ biovar 2, comprised of cool-adapted strains that cause potato brown rot disease (Allen et al. 2001; Clarke et al. 2015). DNA sequencing revealed that the RSSC falls cleanly into four phylotypes, which correspond to geographic origin. Phyl. I strains came from Asia, phyl. II strains from the Americas, phyl. III strains from Africa, and phyl. IV strains from Indonesia and Japan. Phylotypes can be further separated into sequevars based on the sequence of a 750-bp internal fragment of the endoglucanase gene (Fegan and Prior 2005). Based on whole genome sequence data, it has been proposed to divide the RSSC into three species: $R$. solanacearum (containing phylotype II), R. sequeirae (containing phyl. I and III), and R. syzygii (containing phyl. IV) (Remenant et al. 2011). 
American Andes, along with its primary host (Clarke et al. 2015). However, this bacterium is easily transmitted in latently infected seed potato tubers and it is now present in Europe, Asia, Africa, and Australia (CABI 2015). Known historically and for regulatory purposes as Race 3 biovar 2 (R3bv2), it is a quarantine pest in Europe and North America, and a highly regulated Select Agent pathogen in the United States (Lambert 2002; EPPO 2015). R3bv2 also infects geranium, an important ornamental crop that is propagated by cuttings that are often produced in the highland tropics. Geranium cuttings latently infected with $R$. solanacearum R3bv2 have been inadvertently introduced to North America and Europe from Africa and Central America (Strider et al. 1981; Williamson et al. 2002; Janse et al. 2004). To prevent further introductions of this pathogen, regulatory agencies and the ornamental industry have implemented an offshore testing program (APHIS-PPQ 2004).

The known number of plant hosts on which $R$. solanacearum can cause bacterial wilt disease is very large and still expanding. Less is known about the plants that can be colonized by this bacterium without exhibiting symptoms, although hosts like Solanum dulcamara are demonstrably epidemiologically important (Parkinson et al. 2013). The ornamental plant industry, an important economic engine in the developing tropics, transports millions of cuttings internationally each year. We used a recent outbreak on ornamental plants that was associated with $R$. solanacearum to explore the potential of a non-R3bv2 strain to wilt and latently infect ornamental plants.

\section{ISOLATION AND CHARACTERIZATION OF R. SOLANA- CEARUM FROM DISEASED OSTEOSPERMUM}

In December 2014 growers in the United States observed wilting and death of cuttings of Osteospermum, Petunia, Calibrachoa, Verbena, and Lobelia spp. that originated in Escuintla Province, Guatemala (Fig. 1). Initial serological tests with Rs ImmunoStrips (Agdia, Inc., Elkhart, IN) indicated that the plants contained $R$. solanacearum, but this test can not determine if the bacteria belonged to the Select Agent R3bv2 subgroup. Symptomatic cuttings of ten diverse cultivars belonging to the five genera listed above were obtained for further analysis.

Three suspect plants of each ornamental plant species and cultivar were surface sterilized with $70 \%$ ethanol (v/v) and a $0.1 \mathrm{~g}$ slice of stem tissue was macerated and used for direct immunological testing and for enrichment culture in a semiselective medium, as described (Tran et al. 2016). These samples were also used for diagnostic PCR with the $759 / 760$ primers, which amplify a 286-bp band from all strains in the $R$. solanacearum species complex (RSSC), and with the R3bv2specific 630/631 primers (Tran et al. 2016). All plant samples tested positive for $R$. solanacearum with Rs ImmunoStrips, and nine out of ten samples yielded the RSSC-typical 286-bp band following amplification with the 759/760 primers. No PCR

\begin{tabular}{|c|c|c|c|c|c|}
\hline \multicolumn{6}{|c|}{$\begin{array}{l}\text { TABLE } 1 \\
\text { Ralstonia solanacearum strains used in this study. }\end{array}$} \\
\hline $\begin{array}{l}\text { Strain } \\
\text { name }\end{array}$ & Origin & $\begin{array}{l}\text { Isolation } \\
\text { host }\end{array}$ & $\begin{array}{l}\text { Isolation } \\
\text { year }\end{array}$ & $\begin{array}{l}\text { Phylotype- } \\
\text { sequevar }\end{array}$ & Reference \\
\hline UW551 & $\begin{array}{l}\text { Naivasha } \\
\text { Kenya }\end{array}$ & geranium & 2003 & II-1 & $\begin{array}{l}\text { (Swanson } \\
\text { et al. 2005) }\end{array}$ \\
\hline UW568 & $\begin{array}{l}\text { Jutiapa } \\
\text { Guatemala }\end{array}$ & tomato & 2006 & I-14 & $\begin{array}{l}\text { (Sanchez- } \\
\text { Perez et al. } \\
2008)\end{array}$ \\
\hline UW757 & $\begin{array}{l}\text { Escuintla } \\
\text { Guatemala }\end{array}$ & $\begin{array}{l}\text { Osteo- } \\
\text { spermum }\end{array}$ & 2014 & $\mathrm{I}-14$ & This paper \\
\hline $\begin{array}{l}\text { UW757- } \\
\text { gfp }\end{array}$ & & & $\mathrm{n} / \mathrm{a}$ & $\mathrm{I}-14$ & This paper \\
\hline UW758 & $\begin{array}{l}\text { Zacapa } \\
\text { Guatemala }\end{array}$ & tomato & 2015 & $\mathrm{I}-14$ & This paper \\
\hline P781 & $\begin{array}{l}\text { Florida, } \\
\text { USA }\end{array}$ & $\begin{array}{l}\text { Mande- } \\
\text { villa }\end{array}$ & 2012 & $\mathrm{I}-14$ & $\begin{array}{l}\text { (Bocsancz) } \\
\text { et al. 2014) }\end{array}$ \\
\hline GMI1000 & $\begin{array}{l}\text { French } \\
\text { Guyana }\end{array}$ & tomato & 1968 & I-18 & $\begin{array}{l}\text { (Boucher } \\
\text { et al. 1985) }\end{array}$ \\
\hline
\end{tabular}
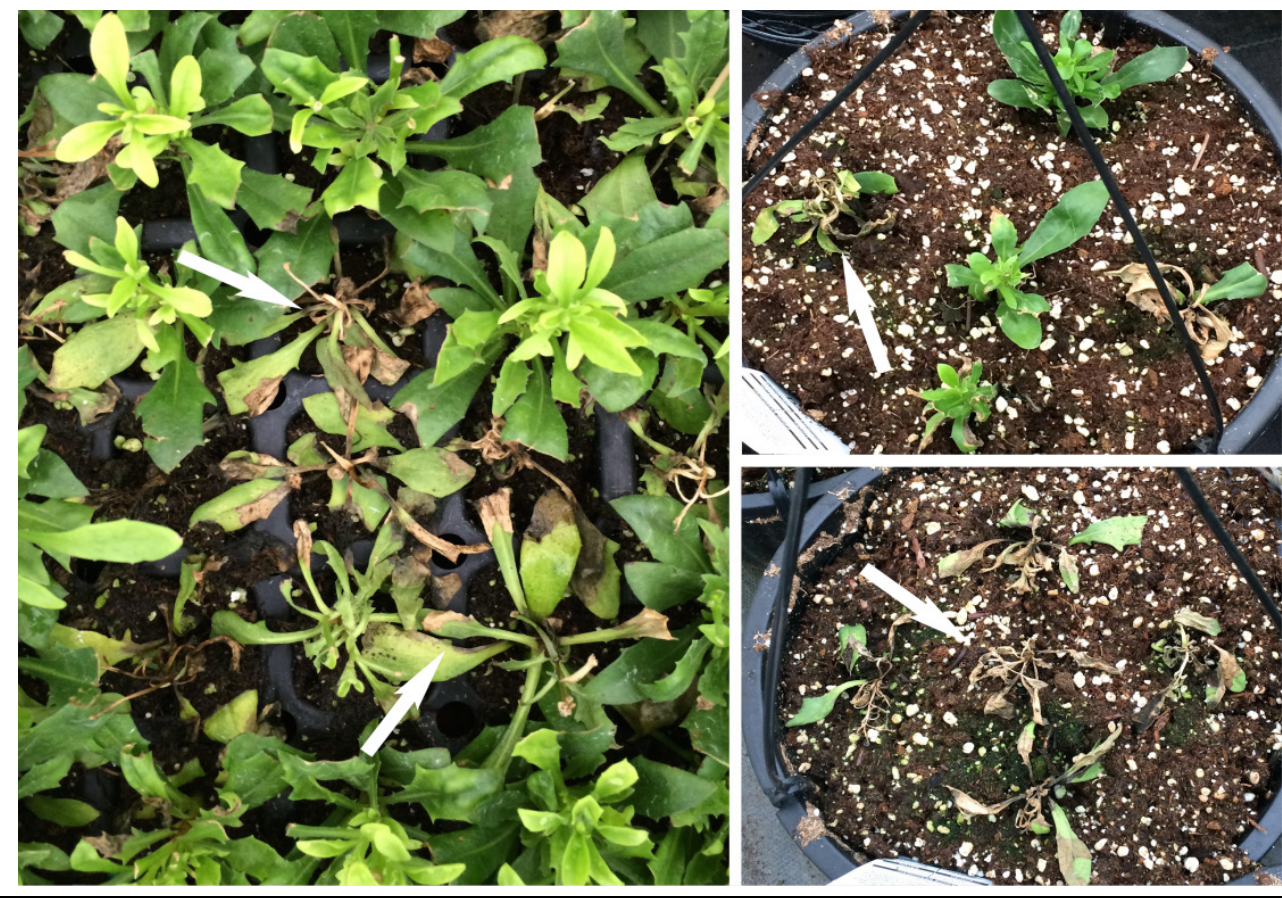

\section{FIGURE 1}

Symptoms initially observed on Osteospermum 'Summertime Kardinal.' Diseased plants were grown from cuttings originating in Guatemala. These plants contained $R$. solanacearum strain UW757 and may have been co-infected with a soft-rot bacterium. 
product was obtained from the tenth sample. However, none of the samples gave a positive PCR result with the R3bv2-specific $630 / 631$ primers, indicating that the plants were not infected with a Select Agent strain of $R$. solanacearum. Enrichment cultures from nine out of the ten samples yielded irregular, slow-growing mucoid colonies that reacted positively with the Rs

ImmunoStrips. One strain, isolated from Osteospermum ecklonis cv. Margarita White, was retained for further analysis and named UW757 (Table 1). Hayward's carbohydrate acidification assay (Hayward 1964) showed that UW757 belongs to biovar 3 .

To characterize this strain at the genetic level, we extracted genomic DNA from overnight cultures of UW757 grown in CPG broth (Hendrick and Sequeira 1984) using the Epicentre MasterPure Complete DNA Purification Kit according to the manufacturer's instructions (Epicentre, Madison, WI). A phylotype-specific multiplex PCR test revealed that UW757 belongs to phylotype I (strains of Asian origin, see Box) (Fegan and Prior 2005). To determine the sequevar of UW757, we amplified and sequenced the strain's $e g l$ gene as described (Tran et al. 2016) and compared it to those of previously characterized strains using MEGA6 and ClustalW (Goujon et al. 2010). Strain UW757 clearly belonged to sequevar 14, with an internal $e g l$ sequence perfectly identical to those of several other characterized $R$. solanacearum strains: P781, UW568, and UW758 (data not shown). P781 was isolated from a wilting mandevilla vine that originated in Florida in 2012 (Bocsanczy et al. 2014). Very similar strains are now established at several mandevilla production sites in southern Florida, where they cause occasional disease outbreaks (D. Norman, personal observation). UW568 is representative of 25 apparently clonal phylotype I seq. 14 strains that were isolated in 2005 and 2006 from tomato, eggplant, soil, and Solanum americanum at diverse locations at mid-level elevations around Guatemala (Sanchez-Perez et al. 2008). UW758 was isolated from a wilting tomato in Zacapa Guatemala in 2015.

\section{WHOLE GENOME SEQUENCING AND PHYLOGENETIC ANALYSIS OF UW757}

To better understand the biology and epidemiology of UW757, we generated a draft genome sequence of strain UW757. Briefly, genomic libraries were constructed using the Illumina TruSeq DNA PCR-Free kit to avoid bias that could be introduced during PCR amplification of the typically high G+C DNA of $R$. solanacearum. These were sequenced on the Illumina Mi-Seq platform (ProteinCT, Madison, WI) using a $2 \times 250$-nucleotide (nt) paired-end sequencing strategy that generated about 3 million reads of up to $250 \mathrm{bp}$ each. Raw data were assessed using FastQC (http://www.bioinformatics.babraham.ac.uk/projects/fastqc) and trimmed using Trimmomatic (Bolger et al. 2014) with Q20 trimming threshold. The Velvet assembler was used for de novo assembly with minimal contig size set to $200 \mathrm{bp}$ (Zerbino and Birney 2008). The sequence was annotated using both RAST (www.nmpdr.org) and NCBI (www.ncbi.nlm.nih.gov) servers. This Whole Genome Shotgun project has been deposited at DDBJ/EMBL/GenBank under the accession LFJP00000000.

The draft genome sequence contains 5,742,407 assembly bases in 223 contigs representing two replicons, as is typical for members of the $R$. solanacearum species complex. Contig sizes ranged from 200 to $356,916 \mathrm{nt}$; more than $50 \%$ of contigs were larger than $129,318 \mathrm{nt}$. To determine the degree of overall relatedness among sequenced $R$. solanacearum strains, we calculated average nucleotide identity (ANI) of homologous genes with MUMmer 3.0 (Table 2) (Kurtz et al. 2004). We also placed UW757 in a larger phylogenetic tree of the $R$. solana-

\begin{tabular}{lcccc}
\multicolumn{5}{c}{ Table 2 } \\
Average Nucleotide Identity (ANI)a among genomes of \\
selected
\end{tabular}

a ANI was calculated using the two-way MUMmer 3.0 algorithm (Kurtz et al. 2004).

cearum species complex, using ANI data from 31 available $R$. solanacearum genome sequences (Fig. 2). As noted above, both UW757 and P781 belong to sequevar 14. However, the comprehensive ANI analysis of these strains' full genome sequences showed that UW757 was more closely related to sequevar 18 strain GMI1000, while P781 was most closely related to strain FQY-4, which belongs to sequevar 14. Nonetheless, UW757 and P781 are very similar; their shared genes are on average almost $99 \%$ identical at the nucleotide level. The divergence between the sequevar classification and the ANI-based trees for this group may be explained by differences in quality among the draft genomes. Our whole genome-based analyses confirmed the phylotype PCR and egl results that placed the strain in phylotype I, closely related to Florida mandevilla strain P781.

Taken together, our findings suggest that the bacterium found in ornamentals produced in Guatemala in December 2014 belonged to a group of phylotype I, sequevar $14 R$. solanacearum strains that are widely distributed in Guatemala, the Caribbean, and Florida.

\section{VIRULENCE AND COLONIZATION ABILITY OF UW757}

To complete Koch's postulates on Osteospermum ecklonis and assess the virulence and colonization ability of UW757 on various hosts, we inoculated 11 different ornamental plant species (listed in Table 3) with this strain. Rooted 3-cm cuttings of each cultivar were grown in 4 -inch pots in a growth chamber at $24 / 22^{\circ} \mathrm{C}$ with a 12-hour day/night cycle to mimic Guatemalan production greenhouse conditions. Once new growth appeared, plants were inoculated. Twenty plants of each variety were inoculated directly by placing a droplet containing 2,000 cells of strain UW757 onto the freshly cut petiole of the first or second leaf, as described (Tans-Kersten et al. 2001). Another 20 plants of each variety were inoculated by soil-soaking, where $10 \mathrm{ml}$ of a bacterial suspension containing $10^{8} \mathrm{CFU} / \mathrm{ml}$ was poured onto the soil of a pot containing an unwounded plant (Tans-Kersten et al. 2001). Twenty 19-day-old tomato plants (bacterial wilt-susceptible cv. Bonny Best) were also inoculated by each method as positive controls. Plants were assessed daily for wilt symptoms. To determine if UW757 could infect any of these hosts without causing symptoms, we measured the bacterial population sizes in the stem of each asymptomatic plant 17 days after petiole inoculation and 18 days after soil-soak inoculation. These dates were chosen because preliminary experiments indicated that inoculated plants that did not develop symptoms by 17 days after inoculation remained asymptomatic until at least 60 days after inoculation. A 0.1 -g cross-section of stem was collected about 2 $\mathrm{cm}$ above soil level ( $1 \mathrm{~cm}$ below the inoculated petiole), ground in water using a Powerlyzer tissue grinder (MoBio, Carlsbad, CA), and serially dilution plated to measure CFU of $R$. solanacearum per gram of stem tissue. The detection limit of this method is about 50 cells/gram stem tissue (Swanson et al. 2007).

All tomato plants inoculated through a cut petiole wilted rapidly and were completely dead after 17 days. About $40 \%$ of 


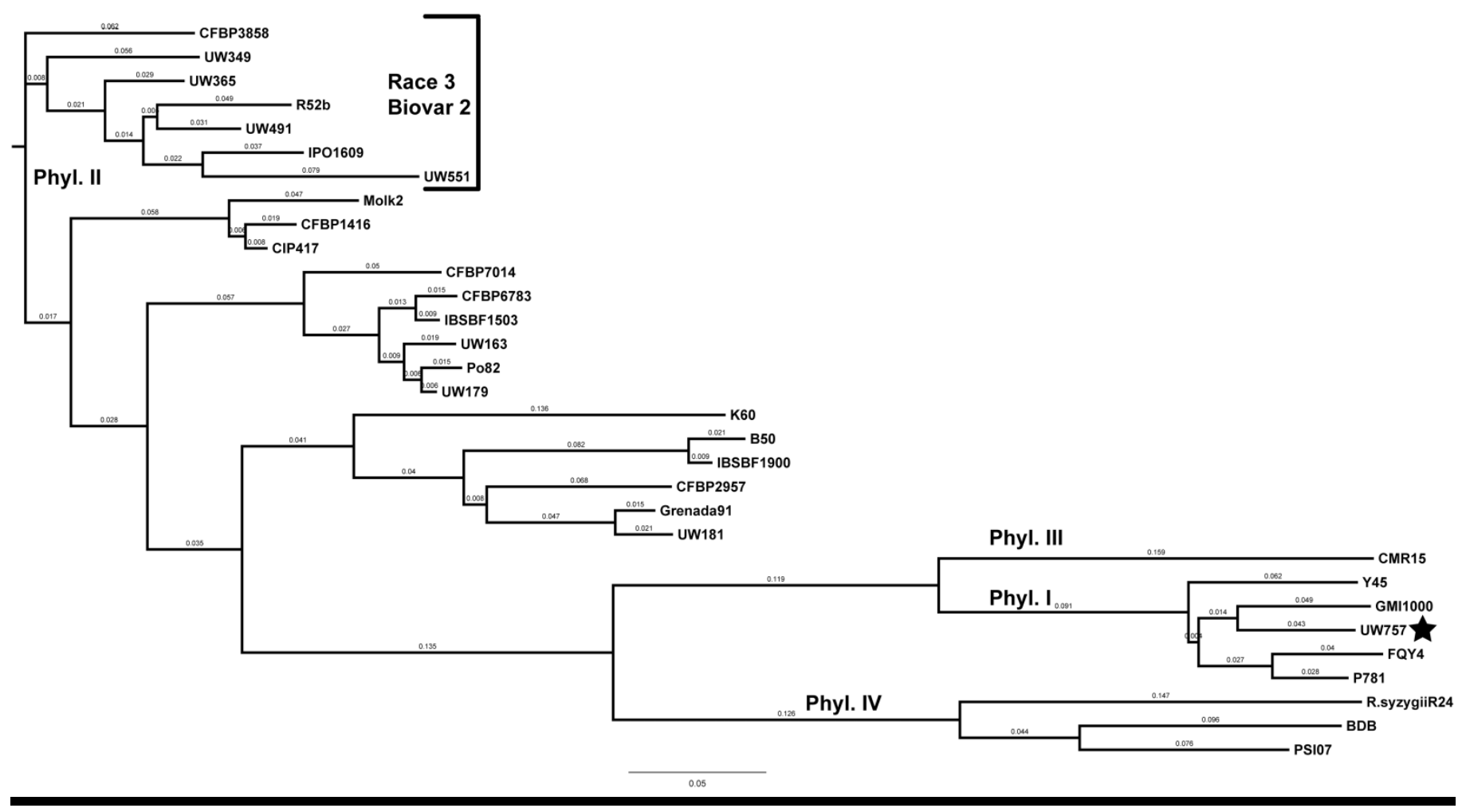

\section{FIGURE 2}

Phylogeny of selected sequenced strains in the $R$. solanacearum species complex. This rooted tree was generated from whole genome sequence datasets using maximum unique match index (MUMi) distances (MUMmer 3.0) and FigTree v.1.4.2 (Rambaut Group, University of Edinburgh). The star indicates the location of strain UW757.

\begin{tabular}{|c|c|c|c|c|c|}
\hline \multirow{2}{*}{ Plant Host } & \multirow{2}{*}{ Symbol } & $\begin{array}{l}\text { BLE } 3 \\
22 / 24^{\circ} \mathrm{C} \text { day } /\end{array}$ & t by $R$. solan & um strain $\mathbf{U}$ & \\
\hline & & \multicolumn{2}{|c|}{ Petiole inoculation ${ }^{a}$} & \multicolumn{2}{|c|}{ Soil-soak inoculation ${ }^{b}$} \\
\hline Dahlia 'Hypnotica Coral' & Dahl & $80 \%$ & $8.91 \times 10^{8}$ & $85 \%$ & $2.88 \times 10^{4}$ \\
\hline Vinca major 'Maculata' & Vinc & $20 \%$ & $1.86 \times 10^{2}$ & $15 \%$ & $2.51 \times 10^{2}$ \\
\hline Pelargonium $\times$ hortorum 'Patriot Bright Red' & Pela & $100 \%$ & $2.21 \times 10^{9}$ & $65 \%$ & $1.99 \times 10^{7}$ \\
\hline Verbena 'Empress Flair Burgundy' & Verb & $45 \%$ & $2.96 \times 10^{3}$ & $30 \%$ & $8.31 \times 10^{2}$ \\
\hline Lobelia erinus 'Bella Aqua' & Lobe & $45 \%$ & $4.38 \times 10^{3}$ & $30 \%$ & $2.27 \times 10^{3}$ \\
\hline Osteospermum 'Summertime Kardinal' & Oste & $85 \%$ & $2.10 \times 10^{5}$ & $75 \%$ & $5.75 \times 10^{4}$ \\
\hline Sutera cordata 'Bahia White' & Sute & $95 \%$ & $4.50 \times 10^{6}$ & $80 \%$ & $1.74 \times 10^{5}$ \\
\hline
\end{tabular}

a Plants were inoculated with 2,000 CFU UW757 via cut petiole inoculation.

${ }^{b}$ Plants were inoculated with $10^{8} \mathrm{CFU} / \mathrm{ml}$ UW757 via soil-soaking inoculation of unwounded roots.

${ }^{\mathrm{c}}$ Numbers indicate the percentage of tested plants that yielded $R$. solanacearum-typical colonies on CPG plates after $48 \mathrm{~h}$ incubation at $28^{\circ} \mathrm{C}$. At 17 days after petiole inoculation or 18 days after soil-soak inoculation, each plant was sampled by serial dilution plating of a ground stem section in triplicate.. Twenty plants were inoculated for each treatment. The limit of detection of this method is $50 \mathrm{CFU} / \mathrm{g} \mathrm{stem}$.

${ }^{d}$ Bacterial population size in host stems was determined via serial dilution plating as described in footnote (c) above. Numbers indicate the mean population size in 20 inoculated plants, with three technical replicates per plant.

the tomato plants inoculated by the soil-soak method developed typical bacterial wilt symptoms by 18 dpi and eventually died (Fig. 5). In contrast, we did not observe wilting or any other noticeable disease symptoms on any inoculated ornamental plants at this relatively cool temperature, with the exception of geranium (Pelargonium $\times$ hortorum 'Patriot Bright Red'). Three petioleinoculated and one soil-soak-inoculated geranium plant exhibited yellowed and dried lower leaves. Additionally, the stems of most inoculated geranium plants had vascular browning even if the foliage was asymptomatic.

Although strain UW757 was not an aggressive pathogen on any tested ornamental plant under these relatively cool conditions, it was an excellent plant colonist. Following direct inoculation into a cut leaf petiole, most or all plants were infected, depending on 

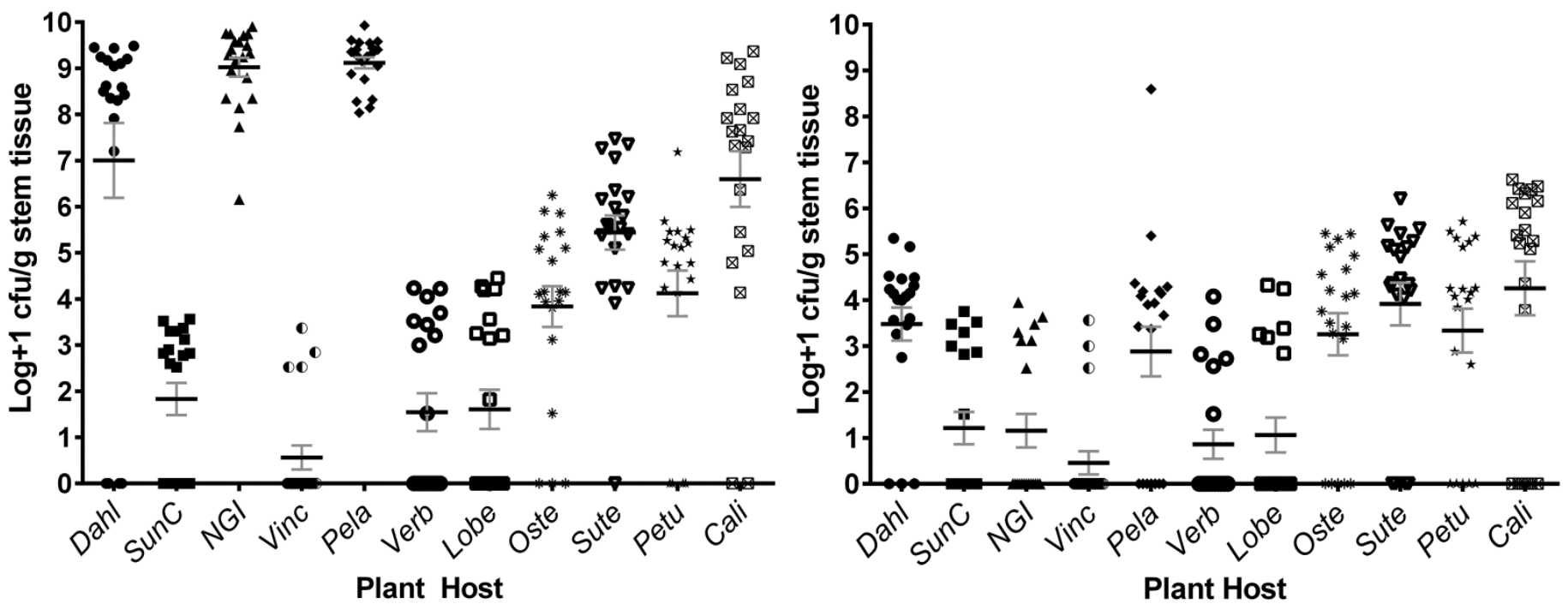

FIGURE 3

Colonization of ornamental plant stems by Ralstonia solanacearum UW757 at $22 / 24^{\circ} \mathrm{C}$ following different inoculation methods. Plants were inoculated with $R$. solanacearum strain UW757 via (A) cut-petiole inoculation with 2,000 cells, or (B) soil-soaking of unwounded plants with a $10 \mathrm{ml}$ suspension of $1 \times 10^{8} \mathrm{CFU} / \mathrm{ml}$. Bacterial population size was determined by serial dilution plating, in triplicate, of ground mid-stem sections at (A) 17 or 18 (B) days post inoculation. The detection limit was $50 \mathrm{CFU} / \mathrm{g}$ stem tissue; all plants without any detectable cells were assigned a value of 1 . Each symbol represents the bacterial population size in an individual plant; black horizontal lines represent the mean midstem population size and gray bars represent the standard error of the mean.

the species, and in many cases the bacterium reached high mean population sizes in plant stems. Seven out of 11 species contained an average of more than 1,000 bacteria per gram of stem (Table 3, Fig. 3A). Fewer plants were infected and the bacterial population sizes were smaller following the less aggressive soil-soak inoculation method (Fig. 3B). Nonetheless, at least $15 \%$ of plants in every tested species contained detectable populations of the pathogen after soil-soak inoculation.

The bacterial population sizes varied widely by host. Few Vinca plants contained any detectable UW757 cells, and those with detectable bacteria contained only a few hundred colony forming units per gram of stem. In contrast, following cut-petiole inoculation most Dahlia, Impatiens, Pelargonium, Sutera, and Calibrachoa plants contained detectable $R$. solanacearum, often at cell densities higher than $10^{8} \mathrm{CFU} / \mathrm{g}$ stem (Table 3). These $R$. solanacearum population sizes are comparable to those observed in tomato and potato plants exhibiting bacterial wilt disease symptoms (Denny 2006).

Because $R$. solanacearum strains generally are more virulent at higher temperatures, we conducted a second virulence and colonization assay at $28^{\circ} \mathrm{C}$ day $/ 24^{\circ} \mathrm{C}$ night. Four plant hosts were petiole-inoculated: Osteospermum, Impatiens hawkeri, Calibrachoa, and Petunia $\times$ atkinsiana. All other conditions were as described above, except that we used a green fluorescent protein (GFP)-expressing variant of UW757 that could be visualized in plant tissue with fluorescence microscopy. This GFP-expressing strain, called UW757-gfp, was constructed using natural transformation to transfer the selectively neutral $g f p$ locus in genomic DNA from $R$. solanacearum strain GMI1000-gfp as previously described (Yao and Allen 2007). Successful transformation was confirmed via fluorescence microscopy. The virulence of this modified strain was indistinguishable from that of wild-type UW757 on both tomato and geranium (data not shown).
In all four host plants tested at the warmer temperature, UW757 reached a higher mean population size than at $22 / 24^{\circ} \mathrm{C}$ (at least $10^{6} \mathrm{CFU} / \mathrm{g}$ stem) (Table 3, Fig. 4). However, despite these high

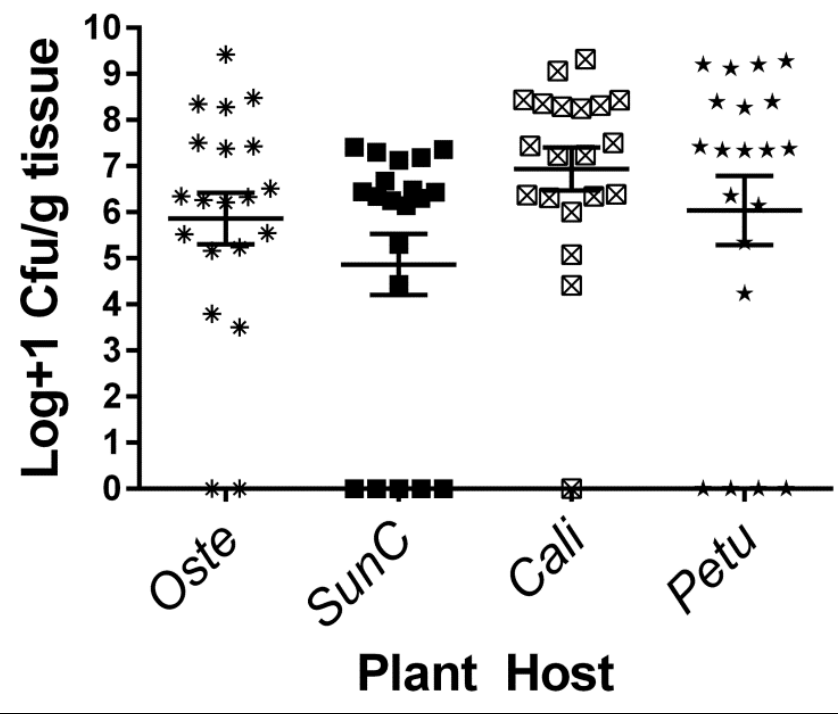

\section{FIGURE 4}

Colonization of ornamental plant stems by $R$. solanacearum at $24 / 28^{\circ} \mathrm{C}$ following petiole inoculation. Twenty plants of each host were inoculated by applying 2,000 cells of $R$. solanacearum strain UW757-gfp onto a cut leaf petiole. Bacterial population size was determined by serial dilution plating, in triplicate, of ground mid-stem sections at 17 days post inoculation. The detection limit was $50 \mathrm{CFU} / \mathrm{g}$ stem tissue; all plants without any detectable cells were assigned a value of 1 . Each symbol represents the population size in an individual plant; black horizontal lines represent the mean midstem population size and bars represent the standard error of the mean. 
colonization levels, we still observed no wilting symptoms on Impatiens, Calibrachoa, or Petunia plants over 60 days following inoculation. One of 20 petiole-inoculated Osteospermum plants incubated at $28^{\circ} \mathrm{C}$ exhibited typical wilting, stem necrosis, and vascular browning (Fig. 5). Ralstonia solanacearum was reisolated from this plant as described above. The isolated bacterium's identity was confirmed by colony morphology, ImmunoStrip test, phylotype multiplex PCR and by direct observation of GFP expression, thus completing Koch's postulates for $R$. solanacearum on Osteospermum.

Because UW757 is genetically similar to mandevilla isolate P781, we petiole-inoculated 15 mandevilla cv. Summer Romance plants to determine if it could also cause disease on this host. Strain P781 was used as a positive control. Twelve of the 15 plants developed wilting symptoms after 28 days at $28^{\circ} \mathrm{C}$, demonstrating that strain UW757 is pathogenic to mandevilla (Fig. 5).
These inoculation studies suggest that under our conditions, UW757 was not an aggressive pathogen of any ornamental plant tested, apart from mandevilla and geranium. It is possible that the symptoms initially observed by commercial greenhouse growers in December 2014 were the result of a synergistic co-infection by $R$. solanacearum and a soft-rotting bacterium that was isolated from one sample. However, although UW757 rarely caused symptoms on Osteospermum in the growth chamber at $28^{\circ} \mathrm{C}$, in the warmer and more humid conditions of a Florida greenhouse, Osteospermum plants almost always wilted following inoculation with either UW757 or P781 (A. M. Bocsanczy and D. J. Norman, unpublished results).

$R$. solanacearum colonizes host plant xylem tissue during active bacterial wilt disease, but its location during latent infection is not known. We used the GFP-expressing variant of UW757 described above to visualize the bacterium in stems of asymptomatic Osteospermum, Impatiens, Calibrachoa, and
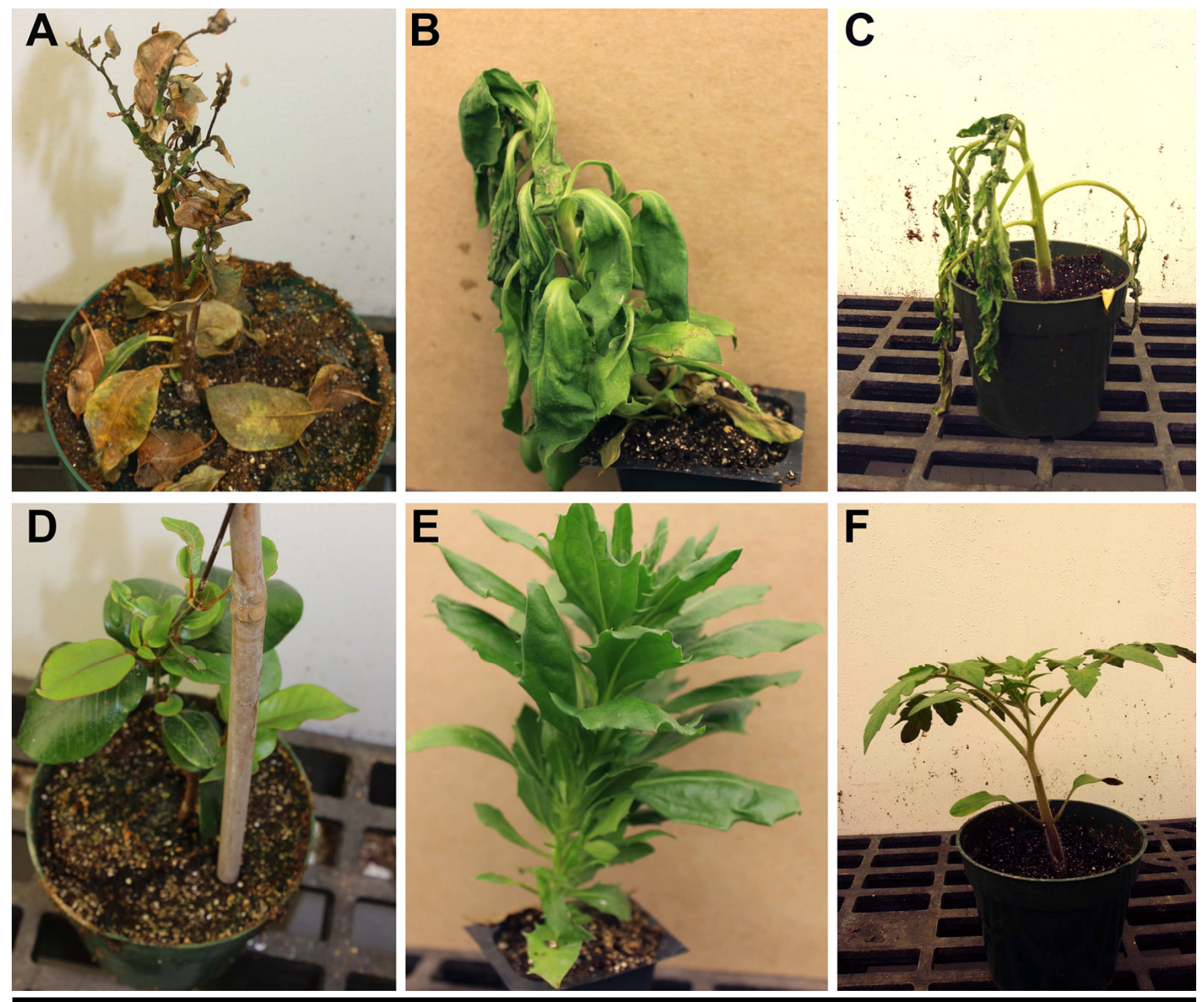

FIGURE 5

Wilting symptoms observed following inoculation of plants with $R$. solanacearum strain UW757. Freshly cut leaf petioles of plants were inoculated with either 2,000 CFU of $R$. solanacearum strain UW757 (A, B, C), or water (D, E, F). Plants shown are mandevilla 'Summer Romance' (A, D), Osteospermum 'Summertime Kardinal' (B, E), and tomato 'Bonny Best' (C, F). 
Petunia plants sampled 14 days after soil-soaking inoculation. Thin stem slices were immediately mounted on glass slides and imaged with visible wavelengths and at $509 \mathrm{~nm}$ emission/395 nm excitation using an Olympus DC73 camera. Bacterial colonization was independently confirmed in five plants per line via fluorescence microscopy. In every case, green fluorescent bacteria were visible in the plant's vascular tissue, suggesting that this pathogen colonizes the same host tissue during asymptomatic and symptomatic infections (Fig. 6).

R3bv2 strains do not induce a hypersensitive response (HR) on tobacco (Allen et al. 2001). The UW757 genome sequence appears to encode the Type III-secreted effectors AvrA and PopP2, which trigger a tobacco HR (Tasset et al. 2010). To determine whether these effectors were functional, we infused fully expanded leaves of tobacco (Nicotiana tabacum cv. Bottom Special) with a bacterial suspension containing $1 \times 10^{8} \mathrm{CFU} / \mathrm{ml}$ of UW757, P781, GMI1000 (positive control), phylotype II sequevar 1 (R3bv2) strain UW551 (negative control), or water
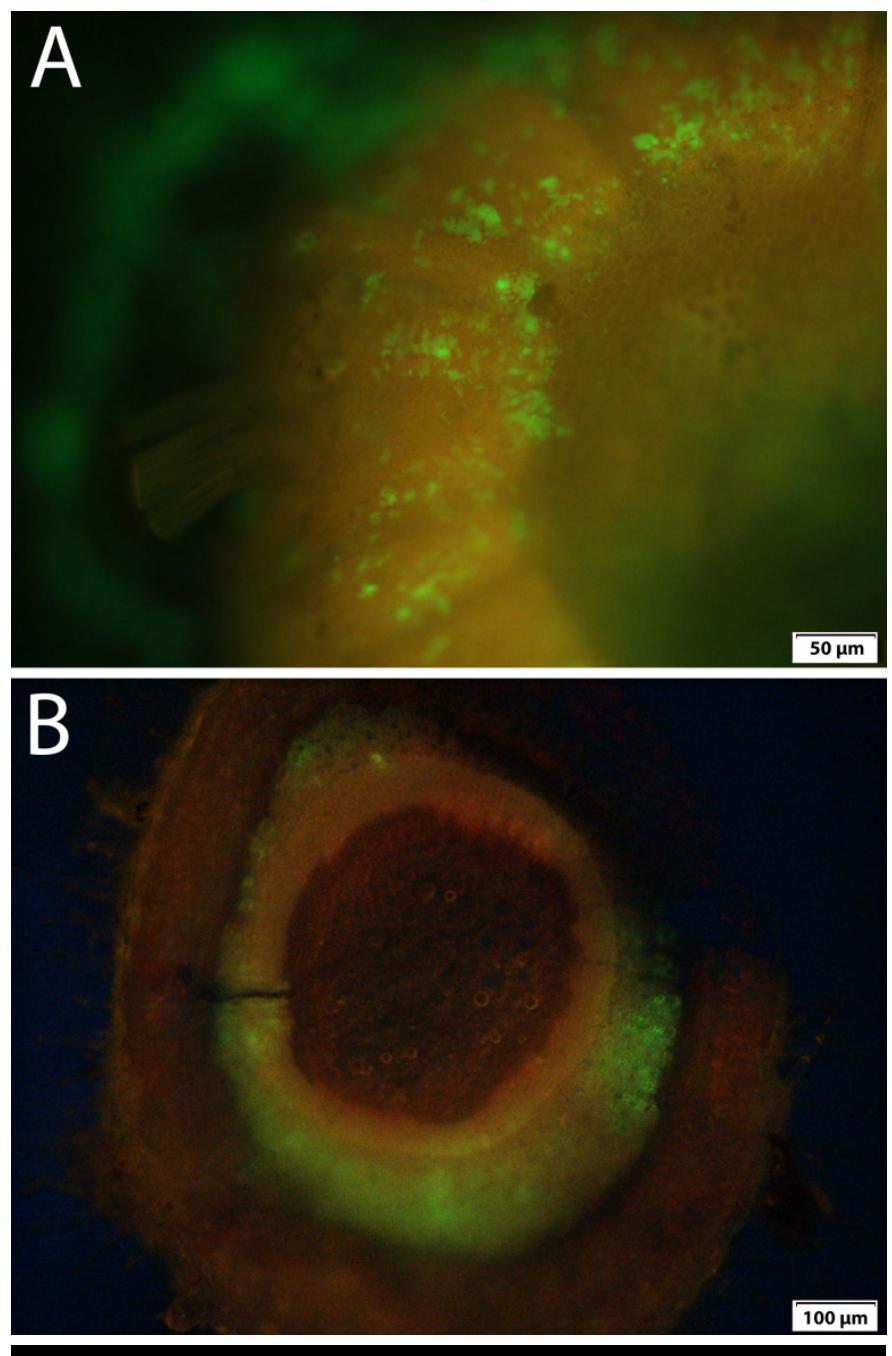

\section{FIGURE 6}

Fluorescence microscopy showing latent colonization of vascular tissue by a GFP-expressing variant of $R$. solanacearum strain UW757. Thin slices were taken from stems of asymptomatic rooted cuttings of (A) Osteospermum 'Summertime Kardinal' and (B) Petunia $\times$ atkinsiana 'Potunia Plus Papaya' plants 14 days after soil-soak inoculation with $R$. solanacearum variant UW757-gfp. These slices were visualized using an Olympus DC73 camera. (negative control). After $24 \mathrm{~h}$ incubation in a $28^{\circ} \mathrm{C}$ growth chamber, UW757, P781 and GMI1000 all caused typical HR-like tissue collapse and desiccation, while UW551 and the water control caused no visible response. Because UW757 causes an HR on tobacco and R3bv2 strains do not, tobacco leaf infiltration could be used as a rapid, easy phenotypic test to distinguish these two groups following a positive ImmunoStrip result.

\section{CONCLUSIONS}

Although $R$. solanacearum sequevar 14 strains did not originate in the Americas, they have been widely present in Guatemala since at least 2005 and in mandevilla production facilities in Florida since at least 2012. Sequevar 14 strain UW757 closely resembles the aggressive tomato-infecting strain UW568, which causes major losses for tomato growers in Guatemala. It is possible that symptomless ornamental plant cuttings carrying large populations of this strain could inadvertently disseminate a serious tomato pathogen. Therefore, high phytosanitation standards in ornamental greenhouses benefit both ornamental and vegetable producers.

We found that strain UW757 easily forms latent infections following inoculation of either wounded or unwounded plants, although at typical Guatemalan cutting production temperatures it rarely caused symptoms on the 11 ornamental species that we tested. Growers and regulators have focused on detecting and excluding $R$. solanacearum R3bv2 from ornamental production farms because it is a highly regulated quarantine pathogen. However, they should be aware that non-R3bv2 strains of $R$. solanacearum can also colonize a broad range of plants including previously unknown hosts. These strains could also threaten U.S. tomato growers. These results offer a reminder that direct biological risks to crops from disease losses may be different from the risks addressed by regulations. Ideally, quarantine and Select Agent regulations should align with real biological threats (Young et al. 2008).

\section{ACKNOWLEDGEMENTS}

The authors gratefully acknowledge donated plants for research from Ball FloraPlant, Lucas Greenhouses, and Dummen. We thank Florent Ailloud and Philippe Prior for expert advice on sequencing and phylogenetic analysis and Frederique Van Gijsegem for help with natural transformation of UW757. This research was supported by the USDAARS Floriculture and Nursery Crop Research Initiative.

\section{LITERATURE CITED}

Allen, C., Kelman, A., and French, E. R. 2001. Brown rot of potatoes. Pages 11-13 in: Compendium of Potato Diseases, W. R. Stevenson, R. Loria, G D. Franc, and D. P. Weingartner, eds. APS Press, St. Paul, MN.

APHIS-PPQ. 2004. Minimum sanitation protocols, testing and sampling plan for off-shore production facilities. 2 November 2004. USDA-APHISPPQ, Pest Detection and Management Programs, Riverdale, MD.

Bocsanczy, A. M., Yuen, J. M. F., Palmateer, A. J., and Norman, D. J. 2014. Comparative genomics of Ralstonia solanacearum strain P781 that infects Mandevilla and Dipladenia plants. Phytopathology 104:S3.1.

Bolger, A. M., Lohse, M., and Usadel, B. 2014. Trimmomatic: A flexible trimmer for Illumina sequence data. Bioinformatics 30:2114-2120.

Boucher, C., Barberis, P., Trigalet, A., and Demery, D. 1985. Transposon mutagenesis of Pseudomonas solanacearum: Isolation of Tn5-induced avirulent mutants. J. Gen. Microbiol. 131:2449-2457.

CABI. 2015. Ralstonia solanacearum (bacterial wilt of potato), datasheet. Invasive Species Compendium. CAB Int., Wallingford, UK.

Clarke, C. R., Studholme, D. J., Hayes, B., Runde, B., Weisberg, A., Cai, R., Wroblewski, T., C.Daunay, M., Wicker, E., Castillo, J. A., and Vinatzer, B. A. 2015. Genome-enabled phylogeographic investigation of the quarantine pathogen Ralstonia solanacearum Race 3 Biovar 2 and screening for sources of resistance against its core effectors. Phytopathology 105:597-607. 
Denny, T. P. 2006. Plant pathogenic Ralstonia species. Pages 573-644 in: Plant-Associated Bacteria, S. S. Gnanamanickam, ed. Springer Publ., Dordrecht, The Netherlands.

EPPO. 2015. European Plant Protection Organization A2 List of pests recommended for regulation as quarantine pests (ver. 2015-09) EPPO/CABI, Wallingford, UK.

Fegan, M., and Prior, P. 2005. How complex is the "Ralstonia solanacearum species complex"? Pages 449-461 in: Bacterial Wilt Disease and the Ralstonia solanacearum Species Complex. C. Allen, P. Prior, and A. C. Hayward, eds. APS Press, St. Paul, MN.

Goujon, M., McWilliam, H., Li, W., Valentin, F., Squizzato, S., Paern, J., and Lopez, R. 2010. A new bioinformatics analysis tools framework at EMBL-EBI. Nuc. Acids Res. 38:695-699.

Hayward, A. C. 1964. Characteristics of Pseudomonas solanacearum. J. Appl Bact. 27:265-277.

Hayward, A. C. 1991. Biology and epidemiology of bacterial wilt caused by Pseudomonas solanacearum. Annu. Rev. Phytopathol. 29:65-87.

Hayward, A. C. 1994a. The hosts of Pseudomonas solanacearum. Pages 9-24 in: Bacterial Wilt: The Disease and its Causuative Agent, Peudomonas solanacearum. A. C. Hayward and G. L. Hartman, eds. CAB Int., Wallingford, UK.

Hayward, A. C. 1994b. Systematics and phylogeny of Pseudomonas solanacearum and related bacteria. Pages 123-135 in: Bacterial Wilt: The Disease and its Causative Agent, Pseudomonas solanacearum. A. C. Hayward and G. L. Hartman, eds. CAB Int., Wallingford, UK.

Hendrick, C. A., and Sequeira, L. 1984. Lipopolysaccharide-defective mutants of the wilt pathogen Pseudomonas solanacearum. Appl. Environ. Microbiol. 48:94-101.

Janse, J. D., Beld, H. E. v. d., Elphinstone, J., Simpkins, S., Tjou-Tam-Sin, N. A. A., and Vaerenbergh, J. v. 2004. Introduction to Europe of Ralstonia solanacearum biovar 2, race 3 in Pelargonium zonale cuttings. J. Plant Pathol. 86:147-155.

Ji, P., Allen, C., Sanchez-Perez, A., Yao, J., Elphinstone, J., Jones, J., and Momol, T. 2007. New diversity and diagnostic challenges associated with Ralstonia solanacearum strains in Florida. Plant Dis. 91:195-203.

Kurtz, S., Phillippy, A., Delcher, A. L., Smoot, M., Shumway, M., Antonescu, C., and Salzberg, S. L. 2004. Versatile and open software for comparing large genomes. Genome Biol. 5:R12.

Lambert, C. D. 2002. Agricultural bioterrorism protection act: Possession, use, and transfer of biological; agents and toxins; interim and final rule. (7 CFR Psrt 331). Federal Register 67:76908-76938.

Parkinson, N., Bryant, R., Bew, J., Conyers, C., Stones, R., Alcock, M., and Elphinstone, J. 2013. Application of variable-number tandem-repeat typing to discriminate Ralstonia solanacearum strains associated with English watercourses and disease outbreaks. Appl. Environ. Microbiol. 79:6016-6022.
Remenant, B., Cambiaire, J.-C. D., Cellier, G., Barbe, V., Medigue, C., Jacobs, J. M., Fegan, M., Allen, C., and Prior, P. 2011. Phylotype IV strains of Ralstonia solanacearum, $R$. syzygii and the blood disease bacterium form a single genomic species despite their divergent life-styles. PLoS One 6:e24356.

Sanchez-Perez, A., Mejia, L., Fegan, M., and Allen, C. 2008. Diversity and distribution of Ralstonia solanacearum strains in Guatemala and rare occurence of tomato fruit infection. Plant Pathol. 57:320-331.

Strider, D. L., Jones, R. K., and Haygood, R. A. 1981. Southern wilt of geranium caused by Pseudomonas solanacearum. Plant Dis. 65:52-53.

Swanson, J., Yao, J., Tans-Kersten, J., and Allen, C. 2005. Behavior of Ralstonia solanacearum Race 3 biovar 2 during latent and active infection of geranium. Phytopathology 95:136-146.

Swanson, J., Montes, L., Mejia, L., and Allen, C. 2007. Detection of latent infections of Ralstonia solanacearum Race 3 biovar 2 in geranium. Plant Dis. 91:828-834.

Tans-Kersten, J., Huang, H., and Allen, C. 2001. Ralstonia solanacearum needs motility for invasive virulence on tomato. J. Bacteriol. 183:35973605.

Tasset, C., Bernoux, M., Jauneau, A., Pouzet, C., Briere, C., KiefferJacquinod, S., Rivas, S., Marco, Y., and Deslandes, L. 2010. Autoacetylation of the Ralstonia solanacearum effector PopP2 targets a lysine residue essential for RRS1-R-mediated immunity in Arabidopsis. PLoS Pathog. 6:e1001202.

Tran, T. M., Jacobs, J. M., Huerta, A. I., Milling, A. S., Weibel, J. A., and Allen, C. 2016. Sensitive, secure detection of race 3 biovar 2 and native U.S. strains of Ralstonia solanacearum. Plant Dis. 100:630-639.

Wicker, E., Grassart, L., Coranson-Beaudu, R., Mian, D., Guilbaud, C., Fegan, M., and Prior, P. 2007. Ralstonia solanacearum strains from Martinique (French West Indies) exhibiting a new pathogenic potential. Appl. Environ. Microbiol. 73:6790-6801.

Williamson, L., Kazuhiro, N., Hudelson, B., and Allen, C. 2002. Ralstonia solanacearum Race 3, Biovar 2 strains isolated from geranium are pathogenic on potato. Plant Dis. 86:987-991.

Yao, J., and Allen, C. 2007. The plant pathogen Ralstonia solanacearum needs aerotaxis for normal biofilm formation and interactions with its tomato host. J. Bacteriol. 189:6415-6424.

Young, J. M., Allen, C., Coutinho, T., Denny, T. P., Elphinstone, J., Fegan, M., Gillings, M., Gottwald, T. R., Graham, J. H., Iacobellis, N. S., Janse, J. D., Jacques, M.-A., Lopez, M. M., Morris, C. E., Parkinson, N., Prior, P., Pruvost, O., Neto, J. R., Scortichini, M., Takikawa, Y., and Upper, C. D. 2008. Plant pathogenic bacteria as bioweapons - Real threats? Phytopathology 98:1060-1065.

Zerbino, D. R., and Birney, E. 2008. Velvet: Algorithms for de novo short read assembly using de Bruijn graphs. Genome Res. 18:821-829. 